\title{
Octavia Estelle Butler'ın Kindred isimli eserinin Türkçe çevirisinde çevirmen kimliği ve çeviri kararlarının yan metinler aracılığıyla incelenmesi
}

\section{Emine KARABULUT'}

APA: Karabulut, E. (2020). Octavia Estelle Butler'ın Kindred isimli eserinin Türkçe çevirisinde çevirmen kimliği ve çeviri kararlarının yan metinler aracılığıla incelenmesi. RumeliDE Dil ve Edebiyat Araştırmaları Dergisi, (20), 670-689. DOI: 10.2900o/rumelide.792311.

$\ddot{\mathbf{O} z}$

Feminist çeviri, kadınlara yönelik baskı, şiddet ve zulümlere karşı bir başkaldırı olarak kadınların sesini uluslar-ötesi boyutta duyurmayı amaçlamaktadır. Bu makalede, Octavia Estelle Butler'ın Kindred isimli eserinin Emek Ergün tarafından Türkçeye çevirisi yapılan ve 2019 yılında İthaki Yayınları tarafından yayımlanan Yakın yan metinsel olarak incelenmiştir. Çalışmada kaynak metin olarak esas alınan Butler'ın eseri Kindred ise 2003 yılında Beacon Press tarafından yayımlanmıştır. Makalenin amacı, çevirmen kimliğini Gérard Genette'nin (1997) öne sürdüğü "yan metin” bağlamında irdelemek ve çeviri kararları ve dayanaklarını örnekleyerek Cecilia Alvstad'ın "çeviride sesler” (2013) ve "çeviri sözleşmesi” (2014) bağlamında çevirmenin söylemsel varlığının çevirmenokur ilişkisini nasıl kurguladığını sorgulamaktır. Makalenin sonucunda, önsöz ve çevirmen notları aracılığıyla, Ergün'ün feminist çevirmen kimliğinin, akademisyen olarak uzman kimliğinin çeviri sürecindeki kararlarını etkilediğine ulaşılmıştır. Bunun dışında, inceleme sonucunda, önsöz ve çevirmen notlarının, Ergün’ün söylemsel varlığını görünür kıldığı, Chatman’in (1978) Anlatısal Bildirişim modeline göre "çıkarsanan yazar" konumunda erek kültürde "çıkarsanan okuyucuyu" oluşturmaya çalıştı̆̆ı ve çeviri sözleşmesi kapsamında bu söylemsel varlığın kendisi ve okuyucuları arasında bir güven ilişkisi oluşturarak okuyucuların çevirisini orijinalmiş gibi okumalarını sağladığı gözlemlenmiştir.

Anahtar kelimeler: Feminist çeviri, çevirmenin kimliği, çevirmenin söylemsel varlığı, çıkarsanan yazar ve çıkarsanan okuyucu, çeviri sözleşmesi

\section{The analysis of translator identity and translation decisions of the Turkish translation of Octavia E. Butler's Kindred through paratexts}

\begin{abstract}
The ultimate purpose of feminist translation is to have the voices of women heard in transnational platform as a rebellion against the oppression, violence, and cruelties implemented on them. In this study, the Turkish translation of Octavia E. Butler's Kindred which was translated into Turkish as Yakın by Emek Ergün and published by Ithaki Publishing House in 2019 was analyzed "paratextually" as put forward by Gérard Genette (1997). The source text in this study, Kindred was published in 2003 by Beacon Press. The aim of this study is to analyze the translator identity in the context of "voices in translation" and "translation pact" asserted by Cecilia Alvstad $(2013,2014)$ and to examine how the discursive presence of the translator fictionalizes the relationship between the translator and the readers by explicating the decisions of the translator and the foundations of the translation. As a result of the analysis in this study, it was observed with the help of her preface and translator notes

1 Öğr. Gör., Erzincan Binali Ylldırım Üniversitesi, Yabancı Diller Yüksekokulu (Erzincan, Türkiye), krbulut.emine@gmail.com, ORCID ID: oooo-0002-6831-2161 [Makale kaylt tarihi: 10.02.2020-kabul tarihi: 20.09.2020; DOI: 10.29000/rumelide.792311]
\end{abstract}


that Ergün's being a feminist translator and expert as an academician in the field affected her decisions in the process of translation. Besides, it was found out that her preface and translator's notes made her discursive presence visible, constituted the "implied reader" in target culture in the position of "implied author" as proposed in Chatman's Narrative Communication Model (1978) and this discursive presence of her enabled the translation to be read as original by the target readers in the scope of translation pact.

Keywords: Feminist translation, translator identity, translator's discursive presence, implied author and implied reader, translation pact

\section{Giriş}

Bu makalenin çıkış noktası, Cecilia Alvstad'ın "The Translation Pact" başlıklı makalesinde “çevirmenin metindeki söylemsel varlığı, okuyucuları çevirinin yabancı metnin doğru anlatımını ilettiğine inandırmaya yönlendirerek okuyucunun çevirmene güvenmesini teşvik eder” şeklindeki ifadesidir (Krş. Alvstad'dan Chesterman, 2014, 275). Bu çıııs noktasından hareketle, makalenin amacı (1) çevirmen kimliğini yan metinler bağlamında irdelemek ve (2) çeviri kararları ve dayanaklarını örnekleyerek "çeviri sözleşmesi" bağlamında çevirmenin söylemsel varlığının çevirmen-okur ilişkisini nasıl kurguladığını sorgulamaktır.

Söz konusu incelemede, Gérard Genette'nin “yan metin”, Cecilia Alvstad’ın “çeviride sesler” ve "çeviri sözleşmesi” ve Chatman'in "çıkarsanan yazar" ve "çıkarsanan okuyucu” kavramları temel alınacaktır. Bahsedilen kavramlar, çevirmen kimliğine ve çevirmenin söylemsel varlığının çevirmen-okur ilişkisini nasıl kurguladığına ışık tutacaktır.

Araştırmanın inceleme nesnesini, Beacon Press tarafından 2003 yılında yayımlanan Octavia Estelle Butler'ın Kindred isimli romanının 2019 yılında İthaki Yayınları tarafından Yakın ismiyle yayımlanan Emek Ergün çevirisi oluşturmaktadır.

Makalede, öncelikli olarak yazar ve çevirmen hakkında bilgi verilecek ve yazarın siyah ${ }^{2}$ bir feminist ve çevirmenin de feminist olması sebebiyle tarihsel süreç içerisinde feminist hareketlerin gelişimine değinilecektir. Daha sonra, uygulama kısmını açıklarken faydalanılacak olan kavramsal çerçeveden söz edilecek, çalışmanın uygulama kısmı örneklerle açıklanacak ve uygulamadan hareketle makalenin amacı doğrultusunda sonuç kısmı eklenecektir. Daha sonra, bahsedildiği üzere uygulama kısmını açıklarken faydalanılacak olan kavramsal çerçeveden söz edilecek, çalışmanın uygulama kısmı örneklerle açılanacak ve uygulamadan hareketle makalenin amacı doğrultusunda sonuç kısmı eklenecektir.

\section{Octavia E. Butler ve Emek Ergün}

Butler, 1947'de Pasena'da Kaliforniya'da doğmuştur ve disleksi olmasına rağmen küȩük yaşta yazmaya başlamıştır. Üniversite eğitimini Kalifornia Eyalet Üniversitesi’nde tamamlamıştır. Yazar Harlon Ellison tarafından keşfedilmesiyle bilimkurgu dünyasıyla tanışmıştır (Krş. İnce, 2018).

"Black”, Ergün’ün de çevirideki dipnotunda bahsettiği gibi Türkçeye genelde "zenci” olarak çevrilmesine rağmen, çalışmanın uygulama nesnesi olan Yakın'da Amerika'daki bağlamında aşağılayıcı maksatla kullanılmaktadır. Oysaki, Türkiye'de "zenci” sözcüğü, Amerika'daki gibi aşă̆llayıcı bir ideoloji ile kullanılmamaktadır. Fakat, uygulama nesnesinde bu şekilde ele alındığından, bu makalede "zenci" sözcüğü değil, kaynak kültürde daha nötr sayılabilecek "siyah" sözcüğü tercih edilmiştir. 
The analysis of translator identity and translation decisions of the Turkish translation of Octavia E. Butler's Kindred through paratexts / E. Karabulut (pp. 670-689)

Butler, “Dahi Bursu” olarak adlandırlan MacArthur Fellowship ödülünü kazanan ilk ve tek bilimkurgu yazarıdır. Bunun dışında, aynı zamanda ilk siyah bilimkurgu yazarı olma ünvanını da taşımaktadır. Bu dönemde, bilimkurgu alanında genelde erkek ve beyazlar egemen olsa da, hem siyah hem kadın olarak bu alanda kendine güçlükle yer edinmiş ve Ursula K. Le Guin, James Tiptree ve Joanna Russ gibi yazarlarla aynı zamanda edebiyat alanında adını duyurmuştur (Krş. Crossley, sonsöz, 336)3.

Edebiyat alanında kendine adını duyuran Butler’ın birçok eseri bulunmaktadır. Crossover isimli öyküsü (1971 yllında Clarion antolojisinde basilır), Patternmaster (1976) ve Kindred (1979) isimli romanları, Speech Sound isimli öyküsü (1984), Bloodchild and Other Stories (1985) isimli novellası, Xenogenesis üçlemesini oluşturan Lilith's Brood (1987), Adulthood Rites (1988) ve Imago (1989) romanları, Earthseed serisinin ilk romanı Parable of the Sower (1993) ve sonrasinda Parable of the Talent (1998) ve Fledgling (2005) isimli romanları bunlar arasında sayılabilir. Fledgling isimli romanı, Algan Sezgintüredi çevirisiyle Yavru Kuş olarak Aylak Adam yayınevi tarafından 2013 yllında Türkçede yayımlanmıştır. Türkçe çeviride dış kapakta belirtildiği üzere hem bilimkurguda hem de Afro-Amerikan edebiyatta bir dönüm noktası sayılabilecek Butler'ın eseri Yakın ise, bir başyapıt niteliğinde olmasına rağmen ilk basım tarihinden tam kırk yıl sonra 2019 yılında Emek Ergün'ün çevirisiyle İthaki Yayınları Bilimkurgu Klasikleri serisinin 43. eseri olarak Türkçeye kazandırılmıştır. Butler’ın sözü edilen bu eserleri, Locus, Hugo, Nebula gibi birçok ödüle layık görülmüştür. (Yakın, 2019, iç kapak).

Butler'ın çocukluk döneminde yaşadığı anıları, Yakın'ı kaleme almasını etkilemiştir. Siyah bir kadın olan annesinin temizlikçi olarak beyaz bir toplumda çalışması, yoksulluktan dolayı annesinin onu işe yanında götürmesi ve bu süreçte gözlemledikleri onun yazarlık hayatını şekillendirmiştir (Krş. Crossley, sonsöz, 334). Butler'ın aşağıdaki sözleri, beyaz insanların siyahlara karşı olan ırkçı ve cinsiyetçi tutumlarını göstermektedir:

İçeriye arka kapıdan girdiğini, kendisi orda dururken sanki orada değilmiş gibi hakkında konuşulduğunu ve aslında insan değilmiş, dikkate değer olmayan bir şeymiş gibi muamele gördüğünü görürdüm...(agy. 334)

Butler, annesinin ve nice siyah kadınların yaşadıklarının berbat olduğunu ve bu yüzden de kendisini bu berbat dünyadan korumak için hayallerine sığındığını belirtmiştir. Böylelikle, Butler, Yakın'da orta sınıf siyahlar tarafından unutulma ve beyaz Amerikalıların siyahları görmezden gelmelerinden kaynaklanan eski nesil siyah Amerikalıların yaşadığı sıkıntıları kurgusal şekilde dile getirmiş̧ir. O halde, Yakın'ın, tarihsel ve psikolojik gerçekliklerin hatırlanmasına yardımcı olduğunu söylemek mümkündür (Krş. agy. 334-336).

Yakın, başkahraman Dana'nın siyah bir kadın olarak yaşadığı deneyimler özelinde, esasında 1815 Amerikan İç Savaşı öncesinde, Güney Amerika'daki tüm siyah kadınların yaşadığı deneyimleri anlatan bir bilimkurgu romandır. Dana'nın 1976 Kaliforniya'sından kurgusal bir zaman yolculuğu ile 1815 yılına atalarının yaşadığı döneme gitmesiyle, Butler, tüm siyahların ve siyah kadınların maruz kaldığı ırkçıllğı, köleliği, cinsiyetçi tutumu ve hatta kimi zaman yoksulluğu gözler önüne sermektedir.

Yakın’ı çevirmeni Ergün ise, Boğaziçi Üniversitesi Çeviribilim bölümünden 2002 yllında ve "Control of Female Sexuality by Medical, Social, and Legal Construction of Virginity in Turkey" başlıklı yüksek lisans tezi ile Maryland Amerika'daki Towson Üniversitesi Women Studies bölümünden 2006 yılında mezun olmuştur. Daha sonra, Baltimore Maryland Üniversitesi'nde disiplinlerarası doktora programını tamamlamıştır. "Doing Feminist Translation as Local and Transnational Activism: The Turkish

$3 \quad$ Aksi belirtilmedikçe çeviriler tarafıma aittir. 
Translation of Virgin: The Untouched History and Its Reception" başlıklı doktora tezinde, feminist çeviriyi ulusal ve uluslar-ötesi politik bir aktivite olarak ele almış ve Hanne Blank'in Bekaretin El Değmemiş Tarihi adlı eserinin Türkçeye çevirisi ve alımlanması üzerine çalışmıştır. Ergün'ün araştırmalarının odak noktası, çevirinin feminist aktivistleri ve hareketleri birleştirmedeki rolüdür. Bahsedilen odak noktası doğrultusunda, Ergün birçok makale, kitap bölümü ve monograf yazmıştır. Amerika'daki North Carolina Charlotte Üniversitesi'nde Global Studies and Women's and Gender Studies bölümünde halihazırda Dr. Öğr. Üyesi olarak görev yapmaktadır. Akademik kimliğinin yanı sıra, Ergün aynı zamanda aktivist bir çevirmendir. Ergün, Luther Link'in Devil: A Mask Without A Face isimli romanını Şeytan: Yüzü olmayan Maske olarak 2003 yllında, Hanne Blank’in Virgin: The Untocuhed History isimli romanını Bekaretin "El Değmemiş” Tarihi olarak 2008 yllında ve Boston Kadın Sağlığı Kolektifi tarafından 2005 yılında yayımlanan ve Bedenim ve Ben olarak Türkçeye aktarılan Our Bodies and Ourselves isimli feminist kadın sağlığı kitabındaki sekiz bölümü ise 2010 yllında çevirmiştir (Krş. Ergün, 2013c). Tüm bu bilgiler ışığında, Ergün’ün hem akademisyen hem çevirmen hem de feminist kimliğinin bulunduğunu söylemek yanlış olmayacaktır. Öyleyse, Ergün'ün feminist politik duruşunun, şüphesiz onun hem akademik hayatındaki araştırmalarının odak noktasını hem de çeviri süreci öncesinde çeviri metnin seçimini ve aynı zamanda çeviri sürecindeki çeviri kararlarını etkilediği düşünülebilir.

Ergün, 2013 yılında yazdığı "Reconfiguring Translation as Intellectual Activism: The Turkish Feminist Remaking of Virgin: The Untouched History" başlıklı makalesinde, feminist bir politik duruşa sahip olma serüveninden bahsetmiştir. 2003 yllında Women Studies bölümüne lisansüstü program için Amerika'ya gitmeden çok önce, Türkiye'deki feminist harekete dahil olduğunu belirtmiştir. Aslında, profesyonel çevirmen deneyimlerinin üniversitedeyken başladığından ve fakat Amerika'ya gittikten sonra aktivist feminist çeviriyi bilinçli bir şekilde anlamlandırdığından ve uyguladığından söz etmiştir. Akabinde, kadınla ilgili konuları ele alan "Pazartesi" isimli feminist bir dergideki haberleri çevirmeye başladığını ve çevirinin Türkiye'deki feminist harekete ve çevirinin bilgi repertuvarını zenginleştirmeye, politik dilbilgisini geliştirmeye ve jeo-epistemolojik görüşlerini genişletmeye yardım ederek ulusal feminist nedenlere hizmet edebileceğini fark ettiğini ifade etmiştir. Böylelikle, Amerika'da yaşarken, çeviri sayesinde "ülkesindeki” feminist aktivizmi gerçekleştirebildiğini belirtmiştir (Krş. Ergün, 2013a, 269, tirnak yazara ait, vurgu bana ait).

İşte tam da bu sebeple, Ergün'ün bilinçli bir feminist olarak hem akademik açıdan feminist uzman ve hem de feminist çevirmen kimliğinin bulunmasının, çalışmada incelenecek eserin seçimini etkilediği söylenilebilir. Bu doğrultuda, yazarın siyah bir kadın ve feminist olması ve çevirmenin de feminist bir kimliğe sahip olmasından dolayı bir sonraki bölümde siyah kadınların verdiği mücadeleler etrafında feminizm ve feminist hareketlerden bahsedilecek ve bu mücadelelerin edebiyat ve çeviriye yansımaları tartışlacaktır.

\section{Feminizm, edebiyat ve çeviri}

Michel feminizmi, "kadınların kendi aralarında bir dayanışma yaratarak erkek egemen dünyanın norm ve değerlerine, cinsiyetçi politikalarına karşı başlatmış olduğu mücadele” olarak tanımlar (Krş. Michel, 1993, 6-7). Tekeli ise feminizmi "kadınların dünyaya, erkeklerin gözlerinden, onların çıarları açısından değil, kendi gözleriyle bakmasını savunan, kendi seslerini bulmalarını isteyen bir düşünce akımıdır" şeklinde tanımlar (Krş. Tekeli, 2017, 131). Feminizm, temelinde "kadın" olan bir harekettir. Dolayısıyla, temelinde "kadın" olan bu harekette kadını ilgilendiren her şey feminizmin de nesnesini oluşturmaktadır. 
The analysis of translator identity and translation decisions of the Turkish translation of Octavia E. Butler's Kindred through paratexts / E. Karabulut (pp. 670-689)

Tarihin çeşitli dönemlerinde kadınlara "iyi eş”, "iyi ana” gibi tanımlamalar aracıllğıyla erkekler gözünden "kadın evreni”ne tutsak etmeye yönelik her adımda feminist bir tepki oluşmuştur (agy. 132). Aynı doğrultuda, Kinser ise, feminizm fikirlerinin 19. yüzyıl ortalarına kadar organize bir hareket olarak boy göstermemiş olsa bile, aslında ilk dalgadan çok daha önce varlığının mevcut olduğunu dile getirmiştir (Krş. Kinser, 2004, 127). Fakat, her türlü çabaya rağmen feministler seslerini duyuramamıştır. Ne zaman ki 1789 Fransız Devrimi'nden sonra "her insan eşittir" fikri yerleşmeye başladı, işte o zaman feministler böyle bir eşitlikten yararlanmak istemişler ve uzun süren mücadelelerden sonra, bu fikir ancak 20. yüzyılın başlarında gerçekleşmiştir (Krş. Tekeli, 2017, 132).

1848 yılında Seneca Falls, New York'ta ilk kadın hakları kongresi yapılmış ve bu kongre dalgalar şeklinde gelecek olan feminizminin başlangıcını oluşturmuştur (Krş. Kinser, 2004, 127). Birinci dalga, AfroAmerikanların kölelik karşıtı özgürlük, eşitlik ve ırksal toplumsal cinsiyete dayalı cinsel istismar mücadelelerinden doğmuştur (Krş. Taylor, 1998, 235). Daha sonra, Afro-Amerikan kadınlar kölelik karşıtı kolektif bir bilinç ile hareket etmeye ve tüm siyah kadınların köleliklerine karşı eşit haklar için mücadele etmeye başlamışlardır (Krş. Taylor'dan Yee, 1998, 236). Bu sebeple, Amerika'daki ırk sorunlarından hareketle, ırkçı, elit Beyaz kadınların isteklerine karşı kendi isteklerini feda etmeyi reddederek küçük burjuvazi feminizme karşı ilk direnişi başlatanların Afro-Amerikan kadınlar olduğunu söylemek şaşırtıcı olmayacaktır. Amerikan tarihi boyunca, Afro-Amerikan kadınlar politik olarak Beyaz kadınlarla mücadele içerisinde olmuşlardır. Politik olarak yaşadıkları deneyimler, Siyah kadınların kendilerine özgü olan bu durumlarını feminist kuram ve eyleme dâhil ederek feminist kuram ve eylemleri şekillendirmişlerdir (Krş. Taylor, 1998, 234).

Collins, Siyah feminist düşüncenin yapılanmasında dört temel faktörün rol aldığını ve bu dört temel faktörün siyah kadının “duruşu”ndan (standpoint) kaynaklandığını belirtir. Öncelikle, Siyah kadınların politik ve ekonomik statüleri onlara bu duruşu kazandırmıştır ve farklı bir fiziksel gerçeklik (material reality) görüşü sunacak deneyimler yaşamalarına neden olmuştur. Siyah kadınların yaptığı ve karşılığında para aldıkları/almadıkları işler, yaşadıkları topluluk çeşitleri, diğer insanlarla olan ilişkileri bir grup olarak Afro-Amerikan kadınların, Siyah ve kadın olmayanlardan farklı bir dünya deneyimlediklerini göstermektedir. İkinci olarak, bu deneyimler bahsedilen fiziksel gerçeklikle ilgili olarak belirli bir Siyah feminist bilincinin ortaya çıkmasına neden olmuştur (Krş. Collins, 1989, 746-747, tırnak yazara ait). Esasında, Siyah feminizmin bu tarihi süreci, sadece Siyah kadınların Beyaz kadınlara karşı düşmanlıklarından değil, aynı zamanda kendi “duruşlarını” güçlendirecek koşulları iyileştirmek ihtiyacından gelişmiştir (Krş. Taylor, 1998, 235).

Bu dönemde bir başka mücadele oy kullanma hakkıyla ilgiliydi. Wells and Barnett, Siyah kadınların kimseye devredilemez oy haklarını korumalarını mümkün kılmak ve okullarını ve işçi olarak yaşam koşullarını iyileştirmek için Beyaz kadınlara göre daha fazla oy hakkına ihtiyacı olduklarına inanmıştır (Krş. Wells and Barnett, 1998, 237).

Simone De Beauvoir'ın İkinci Cins başlıklı kitabı ise, ikinci dalga feminist hareketin öncüsü niteliğindedir ve "Kadın doğulmaz, kadın olunur" ifadesi bu dalganın özünü oluşturmaktadır (Düzkan, 2011, 178). İkinci dalga feminist hareketler, II. Dünya savaşından sonra 1960'larda başlamıştır. AfroAmerikan kadınların kolektif feminist bilincinin esasında bu dalga sırasında geliştiği söylenebilir. Siyah kadınlar, vatandaşlık hakları için mücadele etmişlerdir. Bu mücadeleleri gittikçe büyümüş ve hatta sonrasında hem Siyah hem Beyaz kadınlar kadınların özgürlük hareketine katılacakları politik bir zemin olmuştur (Krş. Taylor, 1998, 239). Diğer bir deyişle, ikinci dalga kadın haklarına, daha da önemlisi kadın özgürlüğüne dikkat çekmiştir (Krş. Kinser, 2004, 129, vurgu yazara ait). 
Son olarak, 1980’lerde ortaya çıkan üçüncü dalga ise, daha çok kişisel kimliğe odaklanan, postmodernizmin yükselmesi sonucunda ortaya çıkan çok seslilikten yana olan ve yargılayıcı olmayan, çoklu bir bakış açısına sahip bir dalgadır (Krş. Snyder, 2008, 193). Buradan hareketle, aslında üçüncü dalganın ırk, sınıf ayrımı, cinsellik ve etnik farklıklarını göz önüne alarak kadınların bunlardan dolayı ezilmesini eleştirdiğini ifade etmek mümkündür.

“Kadınların özgürlüğü öncelikle dilin/dilden özgürlüğü/özgürlük olmalıdır” şeklindeki 1970’lerin sloganı dilin feminist hareketteki önemine işaret etmektedir (Krş. Simon, 1996, 7). O halde, tarihsel süreç içerisinde incelenen bu feminist hareketlerin elbette ki bir de dil ve edebiyat boyutu bulunmaktadır. Sosyal, hukuksal birçok alanda eşitlik ve özgürlük talep eden kadınlar bu mücadelelerini dil ve edebiyat yoluyla da sürdürmüşlerdir.

Batı'daki feminist hareketlerde, özellikle de 1960'lardan sonra ve 1970'lar boyunca, ikinci dalga olarak adlandırılan dönemde, kadınların dünyayı yalnızca "erkek egemenliğine dayalı" (man made) bir dille deneyimledikleri ataerkil sosyo-söylemsel gerçekliği yaratan ve devam ettiren dil, "baskılayanın aracı" olarak görülmeye başladı. Erkek egemenliğine dayalı bir kurum olan dilin, erkeklerin perspektifinden gerçekliği yapılandırarak (bozarak) ve sözcüksel, dilbilgisel ve sözdizimsel yapılar, formlar ve kullanımlar ile erkeğe dayalı kuralları doğallaştırarak ve meşrulaştırarak toplumsal cinsiyet eşitsizliğini güçlendirdiği tartışılmıştır. Bu dönemde, birçok yazar, kadınlara yönelik baskı ve zulümlerin sürekliliğini sağladığı için ataerkil dili eleştirmiş ve bu "erkek egemenliğine dayalı" dilin neden olduğu kadınların görünmezliği ve sesinin duyulamaması konularını tartışmışlardır (Krş. Ergün, 2010, 308). Amerikalı siyah lezbiyen şair, yazar ve aktivist Audre Lorde, Türkçeye Dışarıdaki Kız Kardeş olarak çevrilen Sister Outsider isimli romanında kadınların sesini duyurmanın bir sorumluluk olduğundan bahseder ve şöyle der:

Kadınların sözleri çığlık çığlığa duyulmayı beklerken, o sözleri arayıp bulmaya, okumaya, paylaşmaya ve kendi hayatlarımıza uyup uymadıklarını sorgulamaya dair bir sorumluluğumuz olduğunu hepimiz bilmeliyiz. Bize dayatılmış ve çoğu zaman kendimizinmişçesine kabullendiğimiz ayırıcı safsataların arkasına saklanamayız. (Ergün'den Lorde, önsöz, 7, vurgu bana ait)

Kadınların sesinin duyulması konusunda bilincin artmasıyla birlikte, Cameron da, kadınların dilin bir direniş göstermek, güçlerini gösterebilecekleri ve sosyal değişimleri ifade etmelerini sağlayacak olanaklarını kullanmaları gerektiğinden söz eder:

Feministlerin güçlenmek ve baskı yapmak için dilin sahip olduğu kapasiteye güvenmeleri gerektiğine inanıyorum. Dilsel kaynaklar bizi inkâr etmek için kullanılmış ve hatta bize karşı kullanılmış olabilir, fakat bu ya da bunun gibi bir cinsiyet ayrımıyla ilgili değişmez ve sabit olan hiçbir şey yoktur. Bizim kuramlarımızda kadını "dilin dışına" yerleştirmek aslında kendimizi inkâr etmektir, diğer bir deyişle daha iyi ve farklı bir dünya için ve yeni anlamlar şekillendirebilecek gücü inkâr etmektir. (Ergün'den Cameron, 2010, 309, vurgu bana ait)

Tam da bu gücün farkında olarak, feminist çevirmenler, "kadın düşmanı olmayan" yeni anlamlar yaratmakta ve feminist dilbilim ve çeviribilim arasındaki temel kuramsal kesişiminin ortaya çıttı̆̆ "jino-dost" (gyno-friendly) bir dünyanın var olması için mücadele vermektedirler (Krş. Ergün, 2010, 309, vurgu bana ait). Bu mücadelenin tarihsel süreç içerisindeki gelişiminin, feminist çevirmenlerin böylesi bir dünya yaratmak için gösterdikleri çabayı kanıtlar nitelikte olduğu söylenilebilir. 
The analysis of translator identity and translation decisions of the Turkish translation of Octavia E. Butler's Kindred through paratexts / E. Karabulut (pp. 670-689)

Buradan hareketle, feminist çeviri fikirleri ise, ilk olarak 1970’ler ve 1980’lerin ilk dönemlerinde, "feminist deneye dayah yazım4" (feminist experimental writing) kavramın ortaya çımasını sağlayan dil ile ilgili tartışmaların akabinde Quebec, Kanada'da kök salmıştır. Kadınlar yaratıcıları ve özneleri olarak bu eserlerin merkezinde değildi; aynı zamanda, yazarın cinsiyete dayalı dili eleştirmek ve yapı söküme uğratmak amacını yansıtan yaratıcı dilsel kaynaklar aracılığıyla da merkezdeydiler. Bu sebeple, bu eserlerin çevirilerinde, politik ve yaratıcı dil kullanımı gerekmekteydi ki bu dil kullanımı feminist çeviri pratiklerinin (praxis) ${ }^{5}$ ortaya çlkmasına neden olmuştur (Krş. Ergün, 2010, 309). Bu durumda feminist çevirmenlerin, Spender’in de belirttiği gibi, baskı ve sömürülmenin var olmadığı bir dünyada, yukarıdaki gibi yaratıcı alternatif yollar sunarak kadını özgürleştiren ve güçlendiren çeviriler yaptıkları söylenebilir (Krş. Spender, 1980, 2). Feminist çevirmenler, çeviri pratiğini "politik bir aktivite" olarak görmektedirler (Krş. Ergün, 2010, 312). Susanne de Lotbinie`re-Harwood bir çeviri önsözünde bu durumu şöyle açıklamaktadır:

Benim çeviri pratiğim dilin kadınların için konuşmasını sağlayan "politik bir aktivitedir". Çeviride benim imzamın olması dilde kadını görünür yapmak için her türlü feminist çeviri stratejisini uyguladığım anlamına gelir. Çünkü kadını dilde görünür kılmak gerçek dünyada kadının görülmesini ve sesinin duyulması anlamına gelir. İşte feminizm bundan ibarettir. (Ergün'den de Lotbinie `reHarwood, 2010, 312, italikler tarafıma aittir)

Öyleyse, feminist çeviri, "dişilleştirilmiş"6 (woman-handled) "kadın görünür kılan” çeviridir (Krş. Palacios-Gonza'lez, 2008, 270-271, vurgu bana ait). Dolayısıyla, feminist çevirmenlerin artık "kendini geri planda tutan makul çevirmen yerine metni kadınlaştıran" çevirmenler olarak kadınları görünür kılmaya çalıştıkları söylenebilir (Krş. Godard, 1989, 50, vurgu bana ait). Simon ise, feminist çeviride sadakati farklı bir açıdan değerlendirerek çeviriyi hem yazarın hem de çevirmenin dahil olduğu bir "proje" olarak gördüğünü belirtmektedir (Krş. Simon, 1996, 2, vurgu bana ait). Ergün, Yakın'a yazdığı önsözde çevirisini bir "proje” olarak gördüğünü açıça dile getirmiştir:

[...] Yakın’ çevirmemin birinci nedeni, kitabı okur okumaz, Octavia E. Butler'ın çığlık çı̆̆lığa bağıran sözünün Türkçe'de de duyulması, paylaşılması ve kendimizle ilişkilendirilerek sorgulanması gerektiğine ikna olmamdır. Bu feminist niyetle başlayan Butler’n sözüne ortak olma projesi, şimdi sizin okumalarınızla devam ediyor. (Ergün, 2019, 7)

Bu bağlamda sadakat çevirmenin kendi yorumuna, yazara ve "orijinal” metne ve çevirinin üretildiği hedef okuyucuya ve çeviri metne atfedilen politik misyona karşı politik bir bağlllık anlamına gelmektedir (Krş. Ergün, 2013a, 273). Nitekim, çalışmanın uygulama kısmında detaylı bir şekilde ele alınacak olan Ergün'ün önsözünde, çevirmek için neden bu eseri seçtiğini açıklamasının sebebinin böyle bir sadakat anlayışından kaynaklandığı iddia edilebilir.

4 Ergün, "feminist deneysel yazımı" esas olarak cinsiyetçi bir dil olan Fransızcada gerçekleştirilen, ataerkil dili eleştirme ve yok etme, dilsel olarak kadınları görünür kılma, "dişil yazım" (e' criture fe' minine) olarak bilinen "alternatif bir kadın dili" yaratma konusundaki edebi girişimler olarak tanımlar. Bu yazın daha sonra Cixous, Irigaray, Kristeva, and Wittig gibi Fransız feministler ile ilişkilendirilmiștir (Krş. Ergün, 2010, 309). Yukarıda geçen "e' criture fe' minine" terimi için Prof. Dr. Sündüz Öztürk Kasar tarafindan verilen "Sosyal Bilimlerde Kuram Çevirisi” dersi kapsamında 17.04.2020 yapılan "Kuramsal Kitap İnceleme, Terimce Oluşturma ve Kitaptan Bir Bölüm Çevirme Projesi”nde Kasar'ın önerdiği "dişil yazım" karşılığı kullanılmıștır.

5 Ergün, pratik sözcüğünü, feminist çeviri bağlamında hem politik pratiği kuramsallaştırma hem de politik kuramın pratiğini yapmak șeklinde çift dönüşü bir şekilde kullanır (Krş. Ergün, 2013a, 267-268).

Ergün, "feminist deneysel yazımı" esas olarak cinsiyetçi bir dil olan Fransızcada gerçeklestirilen, ataerkil dili eleștirme ve yok etme, dilsel olarak kadınları görünür kılma, "dişil yazım" ( $e^{\prime}$ criture fe' minine) olarak bilinen "alternatif bir kadın dili" yaratma konusundaki edebi girișimler olarak tanımlar. Bu yazın daha sonra Cixous, Irigaray, Kristeva, and Wittig gibi Fransız feministler ile ilişkilendirilmiştir (Krş. Ergün, 2010, 309). Yukarıda geçen "woman-handling the texts" terimi için Prof. Dr. Sündüz Öztürk Kasar tarafından verilen "Sosyal Bilimlerde Kuram Çevirisi" dersi kapsamında 17.04.2020 yapılan "Kuramsal Kitap İnceleme, Terimce Olușturma ve Kitaptan Bir Bölüm Çevirme Projesi”nde Kasar'ın önerdiği "metinleri dişilleştirmek" karşılığı kullanılmıştır. Buradan yola çıkarak, "woman-handled" teriminin karşılığı olarak "dişilleştirmek" kullanılmıştır. 


\section{Kavramsal çerçeve}

\section{1. Çevirmenin sesi}

Ses, çeviribilimde birçok farklı anlamda kullanılmıştır. Metafor olarak ses, yazar, çevirmen, anlatıcılar, karakterler ve hatta araştırmacılar için kullanılmaktadır (Krş. Alvstad, 2013, 207). Theo Hermans (1996) "Çeviri Anlatıda Çevirmenin Sesi” başlıklı makalesinde "Çevirmenin Sesi” konusuna değinmiştir. Bu makalede, fikirleri temel alınacak olan Alvstad'ın (2013), Hermans’tan hangi noktada ayrıldığını açıklayabilmek adına Hermans'ın açıklamalarına da yer verilecektir.

Hermans, okuyucuların genelde bir yazarın eserinin çevirisini okurken, sözgelimi "Dostoyevski okuyorum" şeklinde doğrudan yazarı okuyormuş gibi davrandıklarını belirtir (Krş. Hermans (çev) Bulut, 1997, 64). Okuyucuların bu davranışının altında yatan sebebi şu şekilde açıklamak mümkündür:

Ses kendini hiçbir zaman açıcça ortaya koymayabilir, ama yine de kimliğini açıç̧a gösterdiği, gözle görülür bir hal aldığı durumlardan güç alınarak varlığının kabul edilmesi doğru olacaktır. Hermans'a göre, bizi bu başka sesin varlığını görmez duruma getiren, çeviri ideolojisinden, saydamlık ve rastlantısallık yanılsamasıyla tek ses yanılsamasından başka bir şey değildir. (agy. 65)

Görüldüğü üzere, okuyucular her ne kadar bu sesi duymuyormuş gibi davransalar da, bu ses varlığını bir şekilde belli etmektedir ve aslında bu bir yanılsamadır. Bu durumun sebebi, çevirmenin "kendini aktarıcının sesinin gerisine" gizlemesinden kaynaklanmaktadır; bir başka deyişle, "birincil ses, etkin ve özgün ses, ortada yoktur. Yine de, genelde o sesin bize sunulan tek ses olduğunu düşünürüz”. Öyleyse, “çeviri roman okurken bize ulaşan ses kimin sesidir?” (agy. 64). Hermans’a göre bu ses, Çevirmenin Sesidir:

Çeviri anlatı söylemi her zaman ikinci bir ses daha taşır, ben buna Çevirmenin söylemsel varlı̆̆ının bir göstergesi olarak Çevirmenin Sesi diyeceğim. Bu ses, kendini az ya da yok ölçüde gösteriyor olabilir. Bütünüyle Anlatıcı'nın arkasına gizlenip çeviri metinde kendine ilişkin bir iz bulunmasını olanaksız kılabilir. Metnin yüzeyine çıkıp kendi adına, kendi adıyla, diyelim metin dışı bir Çeviri’nin Notu'yla, konuşan özneyi niteleyen türden bir kendine göndermeyle, birinci kişi işlevini üstenirse varlığını en doğrudan ve güçlü şekilde göstermiş olur. (agy. 65, vurgu bana ait)

Alvstad ise, "Çeviride Sesler" başlıklı makalesinde, çeviriyi okuyanların yazarın sesine doğrudan ulaşamadıklarını, okuyucuya ulaşan sesin çevirmenin olduğunu ve çevirmenin yazarın sesi izlemini vererek aslında daha önceki söylemi dile getirdiğini belirterek hemen hemen Hermans'ın fikirlerini paylaştığını söylemektedir (Krş. Alvstad, 2013, 208). Yine Hermans ile aynı doğrultuda, Alvstad çevirmenin ve yazarların sesini metin dışından da, örneğin, kapak, önsöz, çevirmen notları aracıllı̆ı ile duymanın mümkün olduğunu belirtmektedir. Alvstad'a göre, çeviri metindeki çevirmen notları gibi örnekler her ne kadar okuyuculara çeviri okuduklarını hatırlatsa da, anlatıcıların ve karakterlerin konuşma şekillerindeki özellikler çeviri olarak metne, diğer bir deyişle, çevirmenin çeviri metindeki söylemsel varlığı ya da sesine dikkat çekebilir (agy. 208-209, vurgu bana ait).

Bahsedilen parallikler dışında, Alvstad Hermans'tan bir noktada ayrılmaktadır: Hermans, çevirmenin "silik" konuşmasını beklediklerinden dolayı okuyucuların çevirmenin söylemsel varhğının farkına varmamış gibi davrandıkların, ancak Alvstad ise okuyucuların çevirmenin söylemsel varhğının farkına varmalarına rağmen, yine de metni orïinalmiş gibi okuduklarını söylemektedir (Krş. Alvstad, 2014, 281, vurgu bana ait). Alvstad'ın bu açlklaması, bir sonraki bölümde detaylı bir şekilde açılanacak olan "çeviri sözleşmesi" kavramına atıfta bulunmaktadır. Dolayısıyla, okuyucuların çevirmen notu veya önsöz aracılığıyla çeviri okuduklarının farkında olmalarına rağmen, uzman ve bilinçli feminist kimliğine 
The analysis of translator identity and translation decisions of the Turkish translation of Octavia E. Butler's Kindred through paratexts / E. Karabulut (pp. 670-689)

dayanarak çevirmenin çevirmen notu veya önsöz yoluyla kaynak metni doğru aktaran kişi olarak okuyucularına güven verdiği ve bu sebeple okuyucuların metni orijinalmiş gibi okudukları düşünülerek bu makalede Hermans'ın değil, Alvstad'ın “Ses” kavramı temel alınmıştır.

Yukarıda sözü geçen kapak, önsöz, çevirmen notları gibi örnekleri, Genette "yan metinler” olarak tanımlar. Genette'ye göre yan metinler, yazar adı, başlık, önsöz, açıklayıcı dipnotlardan oluşan, metni bir kitap haline getiren ve metnin varlığını gösteren yardımcı metinlerdir (Krş. Genette, 1997, 1).

Yan metinlerden çevirmen notlarının işlevlerinden bazılarını, Parlak şöyle sıralamaktadır: Çevirmen notları "(1) Çevirmenin kaynak metnin okuru olarak "kimliğini" görünür ve belirgin kılar. (2) Çevirmenin kendi örnek okurunu 8 nasıl oluşturmaya çalıştığını gösteren veriler sunar. (3) Yazarın söylemsel kurgusuyla yönlendirdiği anlatısal kurgusunun derin yapıdaki iletisini çevirmenin somutladığı okumasıyla ve dipnotlarıyla belirtik hale getirir." (Parlak, 2009, 271, vurgu bana ait). O halde, çevirmenin çevirmen notlarıyla aracılığıyla, erek kültürde kaynak metnin öngördüğü çıkarsanan okuyucuyu oluşturduğu söylenebilir.

Peki çevirmen, erek kültürde kaynak metnin öngördüğü çıkarsanan okuyucuya yan metinler aracıllı̆ıyla ne sunar? Chatman'in Anlatısal Bildirişim şemasına göre, çevirmen okuyucuya "çıkarsanan yazarı" sunmaktadır (Krş. Chatman, 1978). Bu bilgi, doğal olarak akıllarda şu soruların uyanmasına neden olabilir: Çıkarsanan yazar ve çıkarsanan okuyucu kimdir? ya da Çevirmen çıkarsanan yazara nasıl ulaşır? Chatman'e göre, çıkarsanan yazar "[...] okuyucu tarafından anlatı yoluyla yeniden yapılandırılandır (Chatman, 1978, 148). Çıkarsanan yazarın karşılığı ise, "çıkarsanan okuyucudur-... anlatının kendisi tarafından önceden varsaydığı bir okuyucu. Çıkarsanan yazar gibi çıkarsanan okuyucu da her zaman mevcuttur" (Chatman, 1978, 149-150)9. Hermans'a göre, metinlerin kendi kültürlerine ilişkin izler taşımaları, metnin bazı göndermeler içermesi durumunda, Çevirmenin Sesi araya girebilir. Çevirmen, hitap ettiği yeni kitleyle gerekli iletişimi sağlamak adına zorunlu olduğunu düşündüğü bilgileri vermek amacıyla Ses’ini yükseltebilir (Krş. Hermans (çev. Bulut), 1997, 66). Öyleyse, çevirmen, anlatıdan kendi çıkarsadıklarını, diğer bir deyişle, çıkarsanan yazarı okuyucuya sunmaktadır. Çevirmenin, yazdığı önsöz ya da metne eklediği çevirmen notları ile kaynak metnin varsaydığı çıkarsanan okuyucuyu erek kültürde şekillendirebileceği ve yönlendirebileceği düşünülebilir.

Söz konusu yan metinsel öğelerin erek metne eklenmesinin, hem anlatıcı ve karakterlerin seslerinin algılanmasını etkilediği hem de çevirmenin çeviri metinde varlığını görünür kıldığı söylenebilir (Krş. Alvstad'dan May, 2014, 273). Bu yolla varlığını görünür kılan çevirmen ve okuyucuları arasında güvene dayalı bir ilişki kurulur, bir başka deyişle, çeviri sözleşmesi gerçekleşir.

7 Yan metinlerle ilgili daha fazla bilgi için Bkz Pellat (2013); Tahir Gürçağlar (2002); Kovala, U. (1996).

$8 \quad$ Parlak makalesinde, "örnek okur"u "Okuma etkinliği boyunca okur, yeni verilerle, anlatı dünyası hakkındaki bilgisini genişletecek ya da daraltacaktır. Çeşitli çıkarımlar yapacaktır ve belli bir anlamlandırma düzeneğinde ya da birden fazla anlamlandırma düzeneğinde çıarımlarını bireşimsel önermelere dönüştürecektir. Metnin stratejisinin sunduğu okuma izleği ile okurun gelistirdiği bu çkarımsal tutumun örtüsmesi ile örnek okur olusur” seklinde açılamaktadır (Parlak'tan Eco, 2009, 274). Ergün ise, "çıkarsanan okur"u yapısal olarak metnin öngördügü ve anlam yaratmak için aktif olarak metinle iş birliği içerisinde olması gereken varsayılan okur olarak tanımlar (Krş. Ergün, 2013a, 18). Dolayısıyla, "örnek okur”, bu çalışmada, Hermans’n öne sürdüğ̈̈ “çıkarsanan okura” karşllık gelmektedir.

9 Çevirmenin çevirideki söylemsel varlığını açıklamak için önce Schiavi (1996), sonra O'Sullivan (2003) ve daha sonra Munday (2008) çıarsanan çevirmen ve okuyucuyu dahil ederek Chatman'in (1978) Anlatisal İletişim modelini uyarlamışlardır. Fakat Alvstad (2014), çıarsanan çevirmenin Chatman’in modeline entegre edilmesini yersiz bulmaktadır, çünkü çıkarsanan yazar Chatman'in modelinde metnin yapılandırıcı temelidir. Alvstad, Schiavi (1996), O’Sullivan (2003) ve Munday'in (2008) çeviri metinde çıkarsanan yazarın karşıllğ̆ olarak çıkarsanan çevirmeni önermelerine karşı çlkarak hem çeviri metinde hem çeviri olmayan metinlerde okuyucuların çıarsanan yazarı aynı şekilde yeniden oluşturduklarını iddia etmektedir (Alvstad, 2014, 274-275). 


\section{2. Çeviri sözleşmesi}

Çeviriler eleştirmenler tarafından eleştirilirken ya da yorumlanırken, dilsel özellikler ve biçemsel küçük farklar çoğunlukla çevirmene değil de, yazara aitmiş gibi tartışılmaktadır (Krş. Alvstad'dan Venuti, 2014, 270-271). Çeviriler, aslında birçok eyleyen tarafından üretilse de, genellikle bir eyleyen, bir başka deyişle, yazar tarafından üretilmiş gibi okuyucuya sunulmaktadır (Krş. Alvstad, 2014, 270). Venuti'ye göre, çeviri metinlerin yalnızca yazar tarafından üretildiğine dair dominant sosyokültürel bir gelenek mevcuttur ve metinsel ve yan metinsel özellikler de bu geleneği desteklemektedir (Krş. Alvstad'dan Venuti, 2014, 270-271). Bu doğrultuda, çeviri metinler ve çeviri yan metinlerin, okuyucuları çeviri metni orijinalmiş gibi okumaya yönlendirdiği söylenebilir. Bir başka deyişle, yan metinlerin çeviri edebiyatta, okuyucuları çeviri metinleri orijinalmiş gibi okumaya yönlendiren bir yapı olduğu açıtır. İşte bu yapı, Alvstad tarafından çeviri sözleşmesi olarak adlandırılır (Krş. Alvstad, 2014, 270, vurgu bana ait).

Çeviri sözleşmesinin bir parçası olarak, çevirmenin metindeki söylemsel varlığı, okuyucunun çevirmene güvenini sağlayacak ve okuyucuları çevirinin yabancı metnin doğru anlatımını ilettiğine inandıracaktır (Krş. Alvstad'dan Chesterman, 2014, 275). Bu bağlamda, Andrew Chesterman'in Memes Of Translation The Spread Of Ideas In Translation Theory başlıklı kitabında bahsettiği "güven" ve "doğruluk" konusuna değinmek gerekmektedir. Chesterman bu iki kavramın çeviriyle ilişkisini şu şekilde kurar: Çeviriler kaynak metinleriyle çok çeşitli kabul edilebilir şekillerle ilişki kurarlar ve burada önemli olan nokta bu ilişkilerin orijinali doğru yansıtmasıdır (Krş. Chesterman, 1997, 179). Öyleyse, çevirmenin doğruluğu iletme açısından okuyucusuna bir güven verdiği çıkarımında bulunulabilir.

Çevirmenin bu güveni sürdürmesinin yollarından biri kendisini görünür kılmasıdır. Bu amaçla, en azından çevirmenden bahsedilmeli, ancak daha da önemlisi, özellikle daha uzun eserler için, çevirmenin çeviri yaklaşımının altında yatan temel prensipleri açıkladığı bir önsöz ya da buna benzer bir şey bulunabilir. (agy. 182, vurgu bana ait)

O halde, işin içine çeviri sözleşmesi girdiğinde, çevirmenin söylemsel varlığının okuyucuları geleneksel bir şekilde çıkarsanan yazarı yeniden oluşturmaya davet edeceği düşünülebilir. Çevirmenlerin metne müdahalelerini gizlemesine gerek yoktur; aksine, çevirmenler çeviri sözleşmesinin işlemesi için yan metinler aracıllğıyla bu müdahalelerinin söylemi önemli ölçüde değiştirmediğini okuyuculara garanti etmelidir (Krş. Alvstad, 2014, 275) ki bu şekilde çeviri sözleşmesini kabul eden okuyucular, çıkarsanan çevirmene değil de çlkarsanan yazara ulaşırlar ${ }^{10}$. Çeviri sözleşmesi, çoğu zaman üstü kapalı bir şekilde yapılır, ancak çevirmenler önsöz ve dipnotlarda çeviri kararlarını tartışarak eyleyen konumunu açıkça beyan edip kendilerine de dikkat çekebilirler. Çevirmenin söylemsel varlığının muhakkak çeviri sözleşmesine karşı bir tutum sergilediğini söylemek mümkün değildir; hatta, çevirmenler yan metinler aracilı̆̆ıla okuyucuyu çeviri metni belirli bir şekilde okumaya yönlendirdiklerinden (agy. 271) çevirmenin söylemsel varlığının çeviri sözleşmesini güçlendirdiğini söylemek mümkündür (agy. 270).

Alvstad'ın görüşlerinden hareketle, çevirmen adının kapakta olması ya da çevirmenin erek metne dipnotlar eklemesinin çeviri sözleşmesini güçlendirdiği düşünülebilir. Bunun dışında, çevirmenin önsöz yazması da çeviri sözleşmesini güçlendirir ve hatta bu önsözde çeviri zorluklarından bahsetmesi çeviri sözleşmesini düşünüldüğü gibi zora sokmaz; aksine, çevirmenin bu zorlukları tartışması ve onlara çözüm üretme çabası, çevirmenin bilgisini ve çevirisinin okuyucu üzerinde oluşturacağı etkiden haberdar olduğunu gösterir (agy. 276-279). Elbette ki, yan metinlerle oluşturulan sözleşmenin, metinsel kararlarla da desteklenmesi çeviri sözleşmesini güçlendirir. Bu sebeple, çevirmenlerin, biçemsel

10 Bu görüş, çıkarsanan çevirmenle ilgili olarak Munday (2008), O’Sullivan (2003) ve Schiavi’nin (1996) görüşlerinden dipnot 7’de belirtildiği gibi farklılık göstermektedir (Krş. Alvstad, 2014, 270). 
The analysis of translator identity and translation decisions of the Turkish translation of Octavia E. Butler's Kindred through paratexts / E. Karabulut (pp. 670-689)

özelliklere dikkat etmesi ve cinsiyetçi ya da ırkçı ideoloji yüklü açıklamalardan kaçınması gerekmektedir (agy. 280).

Sonuç olarak, çeviri sözleşmesine göre, okuyucular çevirmenin çıkarsanan yazarı doğru bir şekilde kendilerine ilettiğine güvenir ve bu durumda da yazarın doğru aktaranı olarak çevirmenin yaptı̆̆ çeviriyi orijinalmiş gibi okur. Bir diğer deyişle, çevirmenin yan metinler aracılığıyla görünür kıldığı söylemsel varlığının, çevirmen ve okur ilişkisini güvene dayalı şekilde kurguladığı iddia edilebilir.

\section{Uygulama: Yan metinler aracılığıyla çevirmen davranışları ve çeviri kararları}

Öncelikli olarak, İthaki Yayınları tarafından yayımlanan Bilimkurgu Klasikleri içerisinde yer alan Yakın'ın dış kapak sayfası incelendiğinde, çevirmen isminin dış kapakta yer almadı̆̆ı̆, ancak çevirmenin isminin iç kapakta bulunduğu görülmektedir.

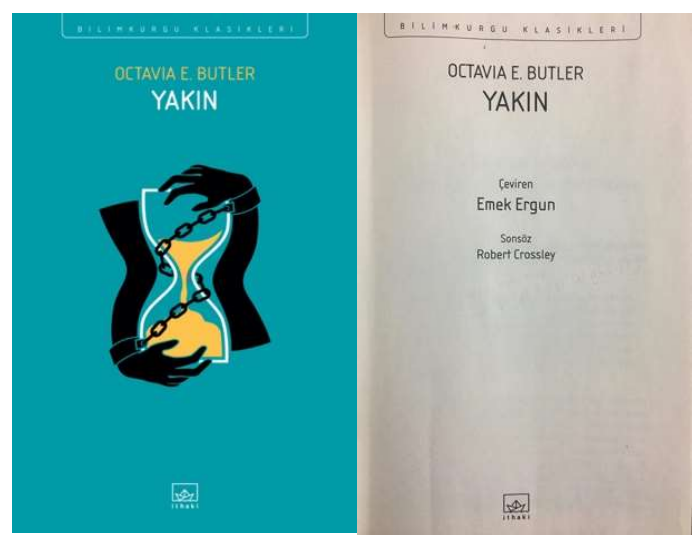

Şekil 1. Yakın Ön Kapak ve İç Kapak

İthaki Yayınlarının Bilimkurgu Klasikleri serisinde yer alan tüm kitaplar incelendiğinde, bu seriye dahil olan hiçbir çeviri romanda dış kapakta çevirmen ismine rastlanmamıştır. Dış kapakta yalnızca yazar isimlerine rastlanmıştır (“İthaki Yayınları", 2017)"1. Bu durum, İthaki Yayınlarının Türk okuyucuların daha çok dikkatini çekeceği düşüncesiyle, Bilimkurgu Klasiklerini sadece yazar isimleriyle öne çlkarmak istemesinden kaynaklanmış olabilir. Dolayısıyla, bu makalenin amaçları doğrultusunda, uygulama örneklerini en açık şekilde açılayabileceği kanısıyla ve çevirmenin söylemsel varlığının en çok hissedildiği yerler olduğu düşüncesiyle, yan metinler, önsöz ve dipnotlar ile sınırlandırılmıştır. Bu sebeple, bu bölümde Ergün'ün çevirmen kimliği ve bu kimliğinin çeviri kararlarına etkisi önsöz ve çevirmen notları aracıllğıyla incelenecektir.

Von Flotow, çevirilerini önsöze yansıtmak ve dipnotlarda metindeki aktif varlıklarını vurgulamak amaciyla dipnot ve önsöz yazmanın feminist çevirmenler tarafindan hemen hemen bir rutin haline dönüştüğünü belirtmektedir (Krş. Von Flotow, 1991, 76). Bozkurt ise, önsöz ve dipnotların feminist çeviri pratiklerinin önemli bir parçası olarak çevirmenleri görünür kıldığını/onların seslerini duyurduğunu ve bu konuda bilinç oluşturmak amacıyla araç olarak kullanıldığını söylemektedir. Feminist çevirmenler, yan metinler aracılığıyla genel olarak feminist çeviri hareketine katkıda bulunabilir ya da ideolojileri ve biçemlerine vurgu yaparak bu niyetlerini ima edebilirler (Krş. Bozkurt, Bu konuda detaylı bilgi için Bkz. http://www.ithaki.com.tr/urun-kategori/edebiyat/bilimkurgu/bilimkurgu-klasikleri/
(27.12.2019) 
2014, 115) ${ }^{12}$. Dolayısıyla, çevirmenin metin seçiminden başlayıp, çeviri sürecinde aldığı kararlar dahil tüm seçimlerinin, kendine ait belirli bir kimliğini okuyuculara yansıttı̆̆ı söylenilebilir.

\title{
4.1. Çevirmenin önsözü: hem uzak, hem yakın bir hikâye
}

Yukarıdaki bilgiler ışığında, çevirmenin metin seçimi ardındaki politik nedenlerin, sonrasındaki çeviri seçimlerini etkilediği düşünülebilir. Bir feminist çevirmen, belirli metin seçtiğinde, onun bu seçimi bir bağllılı, sadakat işareti verir (Krş. Ergün, 2013a, 274). Ergün Yakın'a yazdığ “Çevirmenin Önsözü: Hem Uzak, Hem Yakın bir Hikâye” başlıklı önsözünde çevirmek için özellikle neden böyle bir eser tercih ettiğini detaylı bir şekilde okuyucularıyla paylaşmıştır:

\begin{abstract}
Yakın'ı çevirmemin birinci nedeni, kitabı okur okumaz Octavia E. Butler'ın çı̆̆lık çığlı̆̆a bağıran sözünün Türkçede de duyulması, paylaşılması ve kendimizle ilişkilendirerek sorgulanması gerektiğine ikna olmamdır. Bu feminist niyetle başlayan Butler’nn sözüne ortak olma projesi, şimdi sizin okumalarınızla devam ediyor. Bu söz ortaklığının okurlara nasıl dokunacağını önceden kestirmek zor olsa da, en azından dokunacağını umuyorum; çeviri sürecindeki bütün kararlarımı da dokunsun diyerek aldım...Yakını çevirmemin ikinci nedeni de, kendi feminist yolculuğumda, kuramlarıyla, romanlarıyla, şiirleriyle, aktivizmiyle, dostluklarıyla beni sürekli uyandıran, besleyen, değiştiren ve bana hem ümit, hem de direnme gücü veren Amerikalı siyah feministlere duyduğum minnettir. Yani okuduğunuz çeviri, onlara karşı işleyen dünya düzenine rağmen, siyah feministlerin sözleri yaşasın, sözümüze karışsın diyedir. (Ergün, önsöz, 7-8, vurgu bana ait)
\end{abstract}

Görüldüğü üzere, Ergün, böyle bir metin çevirmesini iki temel neden çerçevesinde açıklamıştır. İlk olarak, bu metin seçiminin, siyah feminist Butler'ın siyah feministlerin geçmişini kurgusal dille anlattığ romanının Türk okuyucularla paylaşılması gerektiğine inanmasından kaynaklandığını belirtmiştir. Metin seçimini etkileyen ikinci nedenin ise, Amerikalı siyah feministlere duyduğu minnet olduğunu söylemiştir. Bunun dışında, Ergün’ün kullandığı "feminist niyetle" ve "kendi feminist yolculuğumda" ifadelerinden yola çlkarak feminist kimliğini ve politik duruşunu açıça okuyuculara gösterdiği söylenebilir. Ergün son cümlesinde ise, çevirisinin amacını - siyah feministlerin sözleri yaşasın, sözümüze karışsın - okuyucular için gözler önüne sermiştir. Kısacası, Ergün’ün hem siyah bir feminist yazar olarak Butler'ın sesini duyurma isteğini dile getirmesi ve bu isteğini kendi feminist kimliğine açıça vurgu yaparak çeviri sürecindeki kararlarıyla ilişkilendirmesinin, yalnızca söylemsel varlığını ortaya koymakla kalmadığı, aynı zamanda, Butler’ın ve eserin feminist bakış açısını doğru aktaran kişi olarak kendisi ve okuru arasında bir güven oluşturduğu iddia edilebilir.

Ergün'ün önsözünde yer alan aşağıdaki ifadenin ise, onun feminist kimliğini açığa vurması ve feminist yaklaşımını duyurma açısından çeviriye atfettiği işlevi ve dolayısıyla kendi çevirisinin amacını açıkça dile getirdiği söylenilebilir:

Kadın yazarların, özellikle de beyaz olmayan kadın yazarların eserlerinin çeviriyle dilden dile aktarılması ve farklı okur kitleleriyle buluşması, hem erkek egemen ve kolonyal yayın dünyasına bir müdahaledir, hem de sını ötesi bir feminist yaklaşım ve dayanışma girişimidir. Çevirinin yakınlaştırıcı potansiyelini, burada siyah feminist bir yazarın sözünü yaymaya adamam tam da bu nedenledir.

Ergün’ün bu sözleri, çeviri yoluyla siyah feminist yazarların sesinin birçok kişiye ulaştığını göstermektedir. Dolayısıyla, bu yazarların sesini, Ergün’ün önsözüyle, yani kendi sesiyle de aktarmak istediği düşünülebilir. Böyle feminist bir eserin çevirisini hem yayın dünyasına bir müdahale olarak hem

12 Rodica Dimitriu, önsözlerin üç işlevi olduğunu belirtmiştir. Bunlar: (1) Çevirmenin metin ve yazar seçimini ve ayrıca çeviri stratejilerini gerekçelendirdiği açıklayıcı işlev (2) Diğer çevirmenler için rehber niteliğinde olan normatif/ kuralcı işlev (3) Çevirmenlerin davranışlarını analiz etmede ipuçları sağlayan belge niteliğindeki alandaki gelecekte yapılacak araştırmalarla ilgili işlev (Krş. Dimitriu, 2009). 
The analysis of translator identity and translation decisions of the Turkish translation of Octavia E. Butler's Kindred through paratexts / E. Karabulut (pp. 670-689)

de feminist bir dayanışma girişimi olarak görerek çevirisinin amacını bir kez daha okuyuculara bildirmiştir. Bu yolla, Ergün’ün bilinçli bir feminist çevirmen olarak çeviri amacını açıkladığı, söylemsel varlığını görünür kıldığı ve sesini okuyuculara duyurduğu iddia edilebilir.

Önsözde dikkati çeken bir diğer nokta ise, Ergün’ün çeviriye dair yaptı̆̆ı yorumlarıyla bilinçli ve uzman çevirmen kimliğini ortaya koymasıdır.

Çeviri esnasında, sözcüklerin taşıdığı anlam yükünün kimi zaman hafiflediği ("kayıp” dediğimiz çeviri olgusu), kimi zamansa arttığı doğrudur. Sonuçta çeviri, farklı kültürel ve tarihsel birikimlerin içinden çıkan iki farklı dilin karşılaşmasıdır. Dolayısıyla bunların metne yansıması doğaldır. Ancak, metnin geçirdiği bu mecburi değişim süreci, Butler’ın sözünü duymamıza engel değildir, çünkü diller ve kültürler arasında sadece farklılıklar ve ayrılıklar değil, benzerlikle ve ortaklıklar da vardır. Önemli olan hem farklılıkları hem de benzerlikleri göz ardı etmeden metni çevirmek ve sözün başka bir dilde, yeni bir okur kitlesiyle karşılaşmasına firsat vermektir... (Ergün, önsöz, 8, vurgu bana ait)

“Kayıp” denilen çeviri olgusundan kaynaklanan çeviri sürecindeki probleme değinen Ergün’ün, kültürel ve tarihsel bir bakış açısıyla dillerin farklılığını ve bu farklılıktan kaynaklanan doğal yansımalarını kabul ettiği görülmektedir. Ergün'ün çeviri sürecinde karşılaştığı düşünülen bu problemi, okuyucularla paylaşması ve tartışması okuyucularıyla arasındaki güven ilişkisini sarsmaktan ziyade bilinçli ve uzman bir çevirmen olarak çeviri süreci hakkındaki bu problem üzerine düşündüğünü gösterebilir ve her ne kadar diller arasındaki farklılıklara dikkat çekse de, benzerlik ve ortaklık olarak nitelendirdiği feminist sözün başka bir dilde söylenmesine vurgu yaparak, çevirisinin amacının, bu feminist yaklaşımı yaymak ve yeni okur kitlesine ulaşmak olduğunu bir kez daha okuyucularına hatırlattığı iddia edilebilir.

Ayrıca, eserin ismini "Yakın" olarak çevirme konusundaki çeviri kararını ise Ergün’ün şu ifadeleriyle belirtmektedir:

[...] Sürükleyici bir hikâye içinde okura, ırkçıllğ̆ın ve cinsiyetçiliğin ortaklaşa yarattığı dehşeti göstererek, önce onları kanlı geçmişleriyle yüzleşmeye; sonra da birlikte, eşitlik, adalet ve özgürlükle tanımlanmış bir gelecek kur(gula)maya çağırır. Gerçeklerden kaçmak için değil, gerçekleri değiştirmek için hayallere sığınmamız gerektiğini, bilimkurgunun tam da bu yüzden eşsiz bir edebiyat türü olduğunu bize hatırlatır. Sadece aklınzla değil, kalbinizle, vicdanınzzla da okumanızı tavsiye ettiğim bu romanın başlı̆̆ını "Yakın" olarak çevirmeyi tercih etmem de bundandır (İngilizcede "kindred," akraba, soy ve benzer anlamlarına gelir). (Ergün, önsöz, 10, vurgu bana ait)

Ergün'ün, önsözünde, eserin ismini "Yakın” olarak çevirme sebebini, yazarın iletmeye çalıştığı mesaj (geçmişin bize yakınlığı) ile bağlantı kurarak açıklamaya çalıştığı söylenebilir. Eserin isminin, Dana'nın geçmişe yolculuğunda kendi akrabalarını ziyaret etmesinden yola çıkılarak konulduğu düşünülürse, çevirmenin, "kindred" sözcüğünün gerçek anlamından (akraba, soy ve vb.) uzaklaşarak yan anlamsal bir boyutta başlı̆̆ı "Yakın” olarak çevirdiği iddia edilebilir. Ergün'e göre, bu yan anlamsal boyutun, eseri, akıl ile değil, kalp ve vicdan ile okumayı gerektirdiği söylenebilir. Ergün bir yandan başlık seçimiyle ilgili çeviri kararını belirtirken, öte yandan burada okuyucuyu eseri nasıl okuması gerektiği konusunda - akıl ile değil, kalp ve vicdan ile - yönlendirdiği, yani, kendi kültüründe çıkarsanan okuru belirlemeye çalıştığı söylenilebilir. Çıkarsanan okur yapısal olarak metnin öngördüğü ve anlam yaratmak için aktif olarak metinle iş birliği içerisinde olması gereken varsayılan okur anlamına gelir (Krş. Ergün, 2013a, 18). Kısacası, Ergün'ün Türk okuyucuları aktif olarak metinle işbirliğine çağırdığı ve metnin öngördüğü okuyucuyu erek kültürde yaratmaya çalıştığı belirtilebilir. Çevirmenin tüm kararlarını açıkça önsözünde belirtmesinin, çevirmen-okur arasındaki ilişkiyi güven açısından sağlamlaştırdığı ve sonuç olarak okuyucuların yazarın doğru aktaranı olarak Ergün'ü rehber kabul ettikleri düşünülebilir. Bu durum, Parlak’’n da dile getirdiği gibi, önsözü okuyan bir okuyucunun şüphesiz kaynak metin okuyucusundan 
daha bilinçli ve daha fazla bilgiye sahip olarak eseri okumasından kaynaklanabilir (Krş. Parlak, 2009, 274).

Bunun dışında, Ergün’ün önsözünde eser ve eserin temasıyla ilgili Tük okuyuculara bilgi verdiği de görülmektedir.

Köleliğin unutulmaya yüz tutmuş vahşetini ve ırkçllı̆̆ın hala yoğun bir şekilde devam eden inkara dayalı şiddetini kadın bakış açısıyla gözler önüne seren Yakın, bugün Amerikan feminist literatürünün klasik romanlarından biri olarak görülür. Bizi ana karakter Dana'yla birlikte zaman yolculuğuna çıkararak, geçmişle bugün arasındaki sürekliliği deneyimlememizi sağlayan ve bir yandan da bize geçmişi hatırlatırken, öte yandan da hatırlamaya dair sorunları açığa vuran roman, böylece egemen kolektif bellek inşasına da müdahale eder. Bizzat yaşamadığımız geçmişin, bize ne kadar uzak görünürse görünsün, aslında çok yakınımızda olduğunu gösterir: Hem kimliğimizi, ilişkilerimizi ve yaşam koşullarımızı belirlemeye devam ettiği için, hem de tekrar edebileceği için...Geçmişin hepten unutulması ya da milliyetçi, rrkçı, erkek egemen söylemin hizmetinde çarpıtılarak yazılması, hem "ötekine" karşı duyulan asılsız nefretin (ve korkunun) nesilden nesile ezbere aktarılmasını sağlar, hem de bu kemikleșmiş kurguların sorgulanmasını zorlaştırır hem de farklılıklarla tanımlanmış topluluklar arasında anlaşmayı, uzlaşmayı ve dayanışmayı sağlar... Yani bir bilimkurgu romanı olarak Yakın'ı geçmişle yüzleşme olmadan kolektif iyileşmenin de olmayacağı fikrini, hayalle gerçeğin kesiştiği eşikte irdeleyen bir hikâyedir. (Ergün, önsöz, 9, vurgu bana ait)

Bu örnekte, Ergün Tük okuyuculara eser hakkında bilgi vererek aslında Butler’ın sözlerini, daha doğru bir ifadeyle, onun sözlerinden çıkarsadıklarını, yani çıkarsanan yazarı okuyuculara sunmaktadır. Ana karakter Dana'nın geçmişe doğru çıktığı kurgusal yolculuğunun aslında sadece geçmişi hatırlatmadığı, aynı zamanda, geçmişteki sorunları da hatırlattığı, hatta bugün ile ilişkilendirmemizi sağladığı söylenilebilir. Bu bakış açısıyla Ergün, bu sorunların kaynağının sosyal hayatla bağlantılı ve geçmişi barındıran kolektif belleğe karşı bir müdahale olduğunu dile getirmektedir. "Ötekine" karşı duyulan milliyetçi, rrkçı ve erkek egemen söylemin gelecekte iyi hale gelmesinin ancak geçmişle yüzleşerek olabileceğini söylemektedir. Buradan hareketle, eser hakkında verdiği bu bilgilerin, Ergün'ün çeviri işini bilinçli bir şekilde yaptığı, feminist alandaki uzmanlık bilgisini okuyuculara açıkça gösterdiği iddia edilebilir.

Genel olarak eserden bahsettikten sonra, Ergün, özel olarak Türk okuyucuları esere şöyle yakınlaştırmaktadır:

Ergün feminist uzman kimliğinin etkisiyle, okuyuculara Yakın'ı ne şekilde okumaları gerektiği konusunda tavsiye vermektedir: İște ceviri...birbirimizi bulmamızı, birbirimizi ișitmemizi, birbirimize değmemizi, birbirimizi değiştirmemizi sağlar. Yani çeviri, birbirimizin hikâyeleriyle katmanlaşarak hayatı döndürmemizi sağlar. Yakın da, izin verirsek, bize dokunabilecek, bizi değiştirebilecek bir romandır çünkü konusu ne kadar bizden uzak görünürse görünsün, aslında, anlattı̆̆ı zulüm ve direniş hikâyesi bize fazlasıyla tanıdıktır. (Ergün, önsöz, 8, vurgu bana ait)

Bu çeviriyi okurken, umarım siz de, hem yakın, hem uzak olan bu hikâyeden esinlenir ve kendi zaman yolculuğunuza çıkarak yüzleşmekten korktuğunuz tarihsel gerçeklerle yüzleşme cesareti bulursunuz. (Ergün, önsöz, 9)

Ergün'ün önsözündeki bu cümleler, yeniden çevirinin işlevinden bahsetmektedir. Türk okuyuculara tanıdık bir hikâye olarak Yakın'ı tanıtıp, bu işlev doğrultusunda, okuyucuları, kendi zaman yolculuklarında yüzleşmekten çekindikleri tarihsel gerçeklerle yüzleşme cesareti bulmaları ümidiyle, okuyucuları, eseri okumaları konusunda yönlendirmektedir. Dolayısıyla, Ergün'ün çıarsanan bir okur oluşturmaya çalıştığı, bu noktada onları yönlendirdiği, okuyucularına tanıdık bir hikâye okuyacaklarını söyleyerek güven verdiği ve en nihayetinde çeviri sözleşmesinin güçlendirdiği iddia edilebilir. 
The analysis of translator identity and translation decisions of the Turkish translation of Octavia E. Butler's Kindred through paratexts / E. Karabulut (pp. 670-689)

Peki, Yakın hangi yönleriyle Türk okuyuculara tanıdıktır? Bu bağlamda, Türk okuyucular eseri nasıl okumalıdır? sorularına da Ergün'ün açıkça cevap verdiği görülmektedir:

\begin{abstract}
Ülkemizin okurları, merkezine köleliği alan bu romanın kendi coğrafi gerçeklikleriyle alakası olmadığı yanılgısına kapılabilirler. Sonuçta, Yakın, "uydurma" bir bilimkurgudur; çeviriyle başka kültürel dünyadan gelmiştir; isimleri bile pek tanıdık olmayan karakterleri, yerleri ve olayları anlatır. Kısacası Yakın, başka bir memleketin, başka bir tarihin, başka bir halkın, başka bir dilin içinden çıkmış bir anlatıdır. Bu hikâye uzağımızda olduğu kadar yakınımızda, hatta içimizdedir de. "Öteki”" olarak kendimize karşı kurgulayıp konumlandırdığımız insanların, sırf "bizden” farklı oldukları (ya "biz" olmayı kabul etmedikleri) için maruz bırakıldıkları sistematik ayrımcılığı, baskıyı ve şiddeti görmemiz için, ille de Yakın’ı okumamıza ya da uzak coğrafyalara bakmamıza gerek yoktur. Ama, yerinden yurdundan edilmiş ya da edilmeye çalışılan bir “ötekinin” yaşadığı haksızhkları, çektiği özlemleri, acıları ve bunlara rağmen hayatta kalmak, özgürce yaşayabilmek için sergilediği direnişi ta içimizde hissetmemiz için, Yakın' okumamız faydah olacaktır. Sonuçta kendimizi "ötekiyle" özdeşleştirmek, onunla duygudaşlık kurmak, sıkça teşvik edildiğimiz ya da alışkanlık edindiğimiz bir eylem değildir. Butler'ın romandaki en büyük ustalığı da işte okura yaşattığı bu duygusal gerçekliktir. (Ergün, önsöz, 10, vurgu bana ait)
\end{abstract}

Görüldüğü üzere, “Yakın’ı okumamız neden faydalı olur?” sorusunun cevabını Ergün önsözünde detaylı bir şekilde açıklamıştır. Yakın’n bir bilimkurgu olmasına rağmen, tarihsel bir gerçeklikten yola çıkılarak "öteki” diye nitelendirilenlerin "bizleşmedikleri” için çektiği zulümleri anlatmak için yazılmış olduğunu ve bu tarihsel gerçeklikle kurgulanmış hikâyenin Türk okurlarına aslında hiç de uzak olmadığını vurgulamaktadır. Okura seslenip Yakın'ı uzak bir coğrafyanın bir hikâyesi değil de aksine yakınlarında bir yerlerde, hatta tam da kendilerinin içinde olan bir hikâye olarak görebileceklerini söyleyerek okur ve kaynak metin arasında bir ilişki kurmaya çalıştı̆̆ı söylenebilir. Bu yönüyle incelendiğinde, çevirmenin yine Yakın'ın neden ve nasıl okunması gerektiği konusunda okuyucuyu yönlendirdiği ve hikâyeyi Türk toplumundaki gerçeklikle karşlaştırarak erek kültürde çıkarsanan okuyucu oluşturmaya devam ettiği gözlemlenmiştir.

\title{
4.2. Çevirmen notları
}

Önsöz incelemesinden sonra, ikinci olarak, çevirmenin kendisi ve okuyucular arasında güvene dayalı ilişki kurması açısından söylemsel varlığını etkin şekilde gösterdiği çevirmen notları incelenecektir. Kaynak metinde hiçbir dipnot bulunmamasına rağmen, Ergün’ün erek metine çevirmen notları eklediği görülmektedir. Aşağıdaki örnekler, bu durumun, Ergün'ün bir uzman olarak çevirmen kimliğinden kaynaklandığı gösterebilir.

\section{Örnek 1:}

\section{Kaynak metin ve Erek metin}

"Where Elisha breathed into the dead boy's mouth, and the boy came back to life. Mama said she tried to stop you when she saw you doing that to me because you were just some nigger she had never seen before." (Butler, 2003, 24, vurgu bana ait)

“Elyesa’nın ölü oğlanın ağzına üflediği ve oğlanın hayata geri döndüğü bölüm. Annem senin de, bana aynısını yaptığını söyledi çünkü daha önce hiç görmediği bir zenciymişsin.” (Ergün, 2019, 32, vurgu bana ait) 


\section{Çevirmen notu}

"Nigger" Türkçeye genelde "zenci” olarak çevrilse de, bu sözcü̆ün İngilizcede, Amerikan köleliğinden ve hala devam eden yoğun Amerikan ırkçılığından beslenen, son derece aşağılayıcı bir sözcük olduğunu vurgulamak gerek. Bugün Amerika'da bir beyazın “nigger” sözcügünü kullanması kabul gören bir şey değildir - ki böyle bir "ayıplamaya” ihtiyaç duyulması bile sözcüğün ifade ettiği ırkçı şiddetin boyutlarına (ve hala yoğun bir şekilde devam ettiğine) işaret eder.

Örnekte görüldüğü üzere, Ergün kaynak metindeki “nigger” sözcüğünü erek dile Türk okuyuculara muhtemelen o dönemdeki ideolojiyi yansıtmak amacıyla "zenci" olarak aktarmıştır. Fakat, alandaki uzmanlığı ve feminist çevirmen kimliği dolayısıyla söylemsel varlığını açıkça ortaya koyan bir çevirmen notu da eklemiştir. Öyleyse, Ergün'ün feminist alandaki uzmanlığının ve feminist çevirmen kimliğinin çeviri kararlarını etkilediği iddia edilebilir. Çevirmen notunda, "zenci” sözcüğünün, temeli Amerikan köle sistemine ve hâlâ da devam eden yaygın Amerikan ırkçılığına dayanan "aşă̆ılayıcı” özelliğine vurgu yapmıştır. Bu sözcüğü telaffuz etmenin, Amerika'da kabul gören bir durum olmadığını ve kullanıldığı bağlamlarda Amerika'da ırkçı şiddetin hala ne kadar çok hissedildiğinin altını çizmektedir. Ergün'ün, bu notuyla bir çevirmen olarak kendi feminist kimliğini yansıtmakla kalmadığı, okuyuculara orijinal metnin altında yatan ideolojiyi kendi çıkarsadığı şekilde - çıkarsanan yazarı- aktardığı ve bu şekilde bu sözcüğü okuyucuların ne bağlamda değerlendirebileceklerini belirtip onları yönlendirerek erek kültürde çıkarsanan okuyucuyu oluşturmaya çalıştığı düşünülebilir. Bunun dışında, bilinçli bir çevirmen izleği sunarak, okuyucularına güven verdiği ve bu anlamda çeviri sözleşmesinin güçlendirdiği iddia edilebilir.

\section{Örnek 2:}

\section{Kaynak metin ve Erek Metin}

Patrols. Groups of young whites who ostensibly maintained order among the slaves. Patrols. Forerunners of the Ku Klux Klan. (Butler, 2003, 37, vurgu bana ait)

Devriyeler. Köleler arasında güya düzeni sağlayan genç beyazlardan oluşan gruplar. Devriyeler. Ku Klux Klan'ın öncüleri. (Ergün, 2019, 32, vurgu bana ait)

\section{Çevirmen notu}

Ku Klux Klan (KKK), beyazların üstün ırk olduğu iddiasıyla, özellikle Amerikan İç Savaşı sonrasında siyahların elde etmeye başladığı hak ve özgürlüklere karşı Güney'de kurulmuş, günümüze kadar faaliyette kalmış ırkçı örgüttür. Cemiyet toplantılarında giydikleri beyaz cüppe ve kukuletalarıyla bilinirler.

Kaynak metinde geçen “Ku Klux Klan” ifadesini, Ergün'ün aynı şekilde aktardığı ve fakat bu ifadeyi bir çevirmen notu ile desteklediği görülmektedir. Çevirmen notunda da belirtildiği gibi, Ku Klux Klan, siyahları kontrol etme görevini üstlenen ve Amerika'nın Güney'inde bulunan onlara baskı, şiddet uygulayan ırkçı bir örgüttür. Çevirmen notu ile söylemsel varlığını görünür hale getiren Ergün'ün, bu örnekte de okuyucuları eserin bilincine vararak okumalarını sağlamak adına yönlendirme niyetinde olduğu söylenebilir. Bu şekilde, çıkarsanan okuru erek kültürde şekillendirdiği ve okuyucuların bu bilgilerle Ergün'ün uzman çevirmen kimliğine güvenerek onun bakış açısını benimsedikleri iddia edilebilir. 
The analysis of translator identity and translation decisions of the Turkish translation of Octavia E. Butler's Kindred through paratexts / E. Karabulut (pp. 670-689)

\section{Örnek 3:}

\section{Kaynak metin ve erek metin}

Rufus. His name brought back all my fear and confusion and longing to go home. Would I really have to go all the way to some northern state to find peace? And if I did, what kind of peace would it be? The restricted North was better for blacks than the slave South, but not much better (Butler, 2003, 39, vurgu bana ait)

Rufus. Adı, bütün korkumu, kafa karışıklığımı eve eve gitme özlemimi tekrar hatırlattı. Huzur bulmak için gerçekten ta Kuzey'de bir eyalete mi gitmek zorunda kalacaktım? Ve öyle olursa bu nasıl bir huzur olacaktı? Kontrollü Kuzey, siyahlar için köleci Güney'den daha iyiydi ama çok daha iyi değildi. (Ergün, 2019, 50, vurgu bana ait)

\section{Çevirmen notu}

Amerika’nın Kuzey eyaletlerinde kölelik, Güney eyaletlerine nazaran daha erken bir tarihte yasaklandığı için "kontrollü Kuzey”, "köleci Güney'den” kaçan köleler için "özgürlük” vaat eden, nispeten daha korunaklı bir bölge olmuştur. Ancak köleliğin yasaklanmasına rağmen ırkçı şiddetin Kuzey’de de devam ettiği gerçeği, siyahların aslında hiçbir yerde tam olarak güvende olmadığı anlamına gelmiştir. (Ergün, 2019, 50-51, italik tarafıma aittir)

Ergün'ün bu notunda, “kontrollü Kuzey” ve "köleci Güney” hakkında Türk okuyuculara bilgi verdiği görülmektedir. Ergün'ün bu tercihi, özelinde siyah kadınlar ve genel olarak tüm siyahlara yönelik baskı ve şiddete dayalı köleliğin, aslında yoğun olarak Güney'de hissedilmesine rağmen, Kuzey'de de var olduğunu ve hatta tüm çevirmen notlarında vurguladığı gibi hâlâ da devam ettiğini kanıtlama düşüncesinden kaynaklanmış olabilir. Türk okuyucularla böyle bir notu paylaşmasının, kendi uzman çevirmen kimliğini yansıtması açısından önemli olduğu düşünülebilir. Bu durumda, her ne kadar çevirmenin söylemsel varlı̆̆ının görünürlüğünün ve metnin çeviri olduğunun farkında olsalar da, okuyucuların kendilerini emin elde hissedip sanki metni orijinal yazar yazmış gibi okudukları iddia edilebilir.

\section{Sonuç}

Feminist çeviri, adalet ve eşitlik arayışı içinde direnişin, dayanışmanın, kültürlerarası diyaloğun ve aktivizmin bir aracı durumundadır (Krş. Castro and Ergun, 2017, 1). Böyle bir misyonla hareket eden feminist çeviriyle beraber, makul, kendini geri planda tutan, okunabilir ve akıcı çeviriler artık eskide kalmıştır (Krş. Von Flotow, 1991, 76). Bunun sebebinin, feminist çevirmenlerin bir bilinç oluşturmak amacıyla okuyucuların çeviriyi akıcı bir şekilde okumalarına önsözler ve çevirmen notları ile çeviriye müdahalelerinden kaynaklandığı düşünülebilir. Öyleyse, feminist çevirmenlerin, çevirmen notları ve önsözler aracılığıyla seslerini duyurdukları, kendilerini görünür kıldıkları ve çıkarsanan yazar olarak erek kültürde kaynak metnin öngördüğü çıkarsanan okuru oluşturmaya çalıştıkları iddia edilebilir.

Feminist çevirmenler, çeviri metinlerin feminist bir bilinçle erek kültüre yolculuk etmesini sağlamak amacıyla çıkarsanan okuyuculara politik olarak bir görev yüklemektedir. Bu yolla, okuyuculara "yabancı bir okuma deneyimi” (Krş. Venuti, 2008, 20) sunarlar ve okuyucunun cinsiyetçi dille ilgili sorunsalları ve politik eleştirilerini arttırmalarını isterler. Kısacası, bu alanlarla üretilen eserler, toplumsal cinsiyet 
ve dil hakkında feminist bilinci arttıran ve/ya da bu bilinci okuma sürecinde değiştiren ortak bir çıkarsanan okuyucu varsayarlar (Krş. Ergün, 2013b, 18).

Makalenin başında da belirtildiği üzere, Octavia E. Butler'ın Yakın isimli eserinin Emek Ergün tarafından yapılan Türkçe çevirisinin inceleme nesnesi olduğu bu makalenin amacı, çevirmen davranışlarını yan metinler bağlamında irdelemek ve çeviri kararları ve dayanaklarını örnekleyerek "çeviri sözleşmesi" bağlamında çevirmenin söylemsel varlığının çevirmen-okur ilişkisini nasıl kurguladığını sorgulamaktır. Hem çevirmenin feminist bir politik duruşa sahip olması hem de eserin yazarının siyah bir feminist olması ve bunun ötesinde eserin konusu itibariyle de siyah feministlerin maruz kaldığı kötü deneyimleri konu alması açısından, makalede öncelikle tarihsel süreç içerisinde feminizmin ve siyah feminizmin ortaya çıkması ve daha sonra ise bunun edebiyat ve çeviri ile bağlantısı açılanmıştır. Bir sonraki aşamada ise, makalenin amacı doğrultusunda, öncelikle makalenin kavramsal çerçevesini oluşturan Genette'den “yan metin”, Alvstad'dan "çeviride sesler” ve "çeviri sözleşmesi”, Chatman'in Anlatısal Bildirişim şemasındaki "çıarsanan yazar" ve "çıarsanan okuyucu" kavramları açıklanmaya çalışılmış ve uygulamadaki örneklerin açıklanmasında bu kavramlardan faydalanılmıştır.

Çevirmenin, çeviri süreci sonunda ürettiği çeviri metindeki kimliğinin, art alan bilgisinin, duruşunun, duyarlılıklarının izini açık ya da gizil şekilde sürmek mümkündür (Krş. Parlak, 2009, 268). Nitekim, inceleme sonucunda, Ergün'ün yazdığı önsöz ve çevirmen notlarının hem Ergün'ün feminist çevirmen kimliğini hem de akademisyen olması dolayısıyla alandaki uzman kimliğini yansıttığını, bu doğrultuda çevirmen notları ve önsözü ile sesini duyurduğu ve kendini görünür kıldığı, diğer bir deyişle, söylemsel varlığını bütünüyle Türk okuyuculara gösterdiği düşünülebilir. İncelenen örnekler, Ergün’ün çevirmen kimliğinin yanı sıra, hem bir akademisyen hem feminist olmasının, çeviriyi erek kitleye yansıtma şeklini ve çeviri kararlarını etkilediğini göstermiştir.

Ergün, feminist çevirinin akıcı okuma sürecini sürekli kestiğine ve okuyuculara çeviri okuduklarını hatırlattığını belirtmiştir (Krş. Ergün, 2013a, 25) Her ne kadar yan metinler okuyucuya o metnin çeviri olduğunu hatırlatsa da, Alvstad'ın önerdiği çeviri sözleşmesi kapsamında, okuyucular yan metinlerin varlığı ile çeviri okuduklarının farkında olmalarına rağmen, çevirmene güven duyarlar ve bu da çeviri sözleşmesini güçlendirir. Makalenin inceleme nesnesi üzerinden açıklayacak olursak, Ergün’ün önsözü ve çevirmen notlarının varlığı ile Türk okuyucuların aslında çeviri okuduklarının farkında olduğu, ancak Ergün'ün önsözünde açıkça ortaya koyduğu feminist çevirmen kimliği ve onun akademisyen olmasından dolayı sahip olduğu uzman kimliği ile okuyucuların gözünde bilinçli bir duruş sergilediği düşünülebilir. Sonuç olarak, bu bilinçli duruş ile Ergün'ün, çıkarsanan yazar konumuna ulaştığı ve feminist politik duruşunu yansıtmak için yazdığı önsöz ve çevirmen notları aracılığıyla erek kültürde çıkarsanan bir okur oluşturmaya çalıştığı iddia edilebilir.

Makalenin, feminist uzman bir çevirmen olarak Ergün'ün erek kültürde çıkarsanan okur yaratarak oluşturmaya çalıştığ feminist bilinci yansıtma konusunda diğer çevirmenlere ışık tutacağı beklenmektedir. Son olarak, bu makalenin, feminizmin yalnızca yaratıcı dil boyutuyla değil de, çevirmen kararları doğrultusunda erek kültüre feminist bilinci aşılama boyutuyla da değerlendirilebileceği ve gelecekteki araştırmacılara bu konuda ilham vereceğine inanılmaktadır. 
The analysis of translator identity and translation decisions of the Turkish translation of Octavia E. Butler's Kindred through paratexts / E. Karabulut (pp. 670-689)

\section{Kaynakça}

Alvstad, C. (2013). Voices in translation. Y. Gambier \& L. van Doorslaer (Ed.), Handbook of Translation Studies içinde, 4, 207-210. Amsterdam: John Benjamins.

Alvstad, C. (2014). Translation Pact. Language and Literature, 23 (3), 270-274.

Bozkurt, S. (2014). Touched Translations in Turkey: A Feminist Translation. Approach. Moment dergi, $1(1), 104-124$.

Butler, O. E. (2003). Kindred. Boston, Massachusetts: Beacon Press.

Butler, O. E. (2003). Yakın (çev. Emek Ergün). Boston, İstanbul: İthaki.

Castro, O. ve Ergün, E. (2017). Introduction : Re-Envisioning Feminist Translation Studies Feminisms in Translation, Translations in Feminism.

Castro O.ve E. Ergun (ed) (2019). Feminist Translation Studies: Local and Transnational Perspectives içinde, New York: Routledge.

Chatman, S. (1978). Story and Discourse: Narrative Structure in Fiction and Film. Ithaca, NY: Cornell University Press.

Chesterman, A. (1997). Memes of Translation the Spread of Ideas in Translation Theory. Amsterdam/Philadelphia: John Benjamins Publishing Company.

Crossley, R. (2003). Eleştirel Makale. Butler, O. E. Yakın içinde. İstanbul: İthaki Yayınları.

Dimitriu, R. (2009). Translators' prefaces as documentary sources for translation studies. Perspectives: Studies in Translatology, (17) 3, 193-206.

Düzkan, A. (2011). İkinci Dalga Feminizm. İstanbul - Amargi Feminizm Tartışmaları içinde. İstanbul: AMARGİ S.S. Kadın Bilimsel Araştırma ve Dayanışma Yayıncılık Kooperatifi,174-193.

Ergün, E. (2010). Bridging Across Feminist Translation and Sociolinguistics. Language and Linguistics Compass, 4 (5), 307-318, 10. 1111/j.1749-818x.2010.00208.x

Ergün, E. (2013a). Reconfiguring translation as intellectual activism: The Turkish feminist remaking of virgin: The Untouched History. Trans-Script, 3: 264-289.

Ergün, E. (2013b). Feminist Translation and Feminist Sociolinguistics In Dialogue: A multi-layered Analysis of Linguistic Gender Constructions In and Across English and Turkish. G\&L Gender and Language, 7 (1), 13-33.

Ergün, E. (2013c). Emek Ergün [Online] Erişim Adresi http://emekergun.gandi.ws/cv

Ergün, E. (2019). Çevirmenin Önsözü: Hem Uzak, Hem Yakın Bir Hikâye. Butler, O. E. Yakın içinde. İstanbul: İthaki Yayınları, 7-11.

Genette, G. (1997). Paratexts: Thresholds of Interpretation. Tr. Jane E. Lewin. Cambridge: Cambridge University Press.

Godard, B. (1989). Theorizing feminist discourse/Translation. Tessera, 6 (Spring), p. 42-53.

Hermans, T. (1997) "Çeviri Anlatıda Çevirmenin Sesi” (çev. Alev Bulut). Kuram, No:15, İstanbul: Kur Yayınları, İstanbul, 63-68.

İnce, M. (2018, 30 Kasım). Siyahi, Yalnız Ve Hep Aykırı: Octavia E. Butler. https://www.kayipdunya.com/muge-ince/siyahi-yalniz-ve-hep-aykiri-octavia-e-butler

İthaki Yayınları. (2017). Bilimkurgu Klasikleri. Erişim Adresi http://www.ithaki.com.tr/urunkategori/edebiyat/bilimkurgu/bilimkurgu-klasikleri/

Kinser, A., E. (2004). Negotiating Spaces for/through Third-Wave Feminism. NWSA Journal, 16 (Autumn), (3), 124-153.

Kovala, U. (1996). Translations, Paratextual Meidation and Ideological Closure. Target, 8 (1). 119-47.

Michel, A. (1993). Feminizm. İstanbul: İletişim. 
Palacios-Gonza'lez, M. (2008). The gender of translation: Irish poetry in Galician. Babel, 54(3). 26880.

Parlak, B. (2009). "Yazınsal Ceviride Kaynak Metnin Okuru/Erek Metnin Yazarı Olarak Cevirmen Kimliğinin Çeviri Kararlarına Etkisi”. Çeviribilim, Dilbilim ve Dil Eğitimi Araştırmaları, 267280.

Collins, P., H. (1989). The Social Construction of Black Feminist Thought. Signs, 14 (4), 746- 745-773.

Pellatt, V. (2013). "Introduction.” Text, Extratext, Metatext and Paratext in Translation. UK: Cambridge Scholars Publishing, 1-6.

Simon, S. (1996). Gender in Translation: Cultural Identity and the Politics of Transmission. London; New York: Routledge.

Snyder, R., C. (2008). What Is Third-Wave Feminism? A New Directions Essay. Signs (Autumn), 34 (1) 175-196.

Spender, D. (1980). Man made language. London: Routledge \& Kegan Paul.

Tahir Gürçağlar (2002). "What Texts Don’t Tell: The Use of Paratexts in Translation Research". Theo Hermans (ed.), Crosscultural Transgressions. Research Models in Translation Studies II: Historical and Ideological Issues içinde, Manchester: St. Jerome.

Tekeli, Ş. (2017). Feminizmi Düşünmek. İstanbul: İstanbul Bilgi Üniversitesi.

Taylor, U. (1998). The Historical Evolution of Black Feminist Theory and Praxis. Journal of Black Studies, 29 (2), 234-253.

Venuti, L. (2008). The Translator's Invisibility. 2nd ed. New York: Routledge.

Von Flotow, L. (1991). Feminist Translation: Contexts, Practices and Theories. TTR, 4 (2), 69-84. 